\title{
Paraenese of paraklese as generiese terme vir Nuwe-Testamentiese moral exhortation?
}

\author{
Jan Botha \\ Departement Godsdienskunde \\ Universiteit van Stellenbosch \\ STELLENBOSCH \\ $\&$ \\ Fika J. van Rensburg \\ Departement Klassieke en Semitistiek \\ TSP/PU vir CHO \\ POTCHEFSTROOM
}

\begin{abstract}
Paraenesis or paraclesis as generic terms for New Testament moral cxhortation?

In the first two issues of In die Skriflig ( 1990 ) a series of anicles was published in which the relation between indicative and impenuive in the New Testament was considered from different angles. The authors of those anicles use paraclesis as a generic term for New Testament moral exhortation. In this aricle the validity of this use of the tern paraclesis is investigated. It is argued that paractesis may be used as a tern denoting a sub-category of the parainetic literature of the New Testament. The nature of the moral cxhortation in different New. Testament writings is investigated, and it is concluded that by using a term for one possible sub-genre as a generic tern, the variety and imporiant differences in New Testament moral cxhortation are ignored. The well-known tern paraenesis is then considered as a generic tem, but is also rejected. Paracnesis has, as a technical term, a more specific reference, and does not convey the variety of moral cxloriation in the New Testament.
\end{abstract}

\section{INLEIDING}

Dit is algemeen bekend dat die meeste briewe in die Nuwe Testament dele bevat wat op een of ander wyse 'n appèl op hulle lesers maak tot (i) die aanvaarding en uitlewing van 'n nuwe waardesisteem en lewenswyse, of (ii) 'n aanmoediging om met 'n bepaalde lewenswyse voort te gaan en vas te hou aan en sterker te staan in 'n reeds aanvaarde waardesisteem, of (iii) wat 'n vermaning of waarskuwing oor 'n verskeidenheid sake voorhou, of (iv) wat 'n vertroosting van een of ander aard aan hulle lesers aanbied. Vanweë die uiteenlopende aard en funksies van hierdie soort taalgebruik in die NuweTestamentiese briewe, is dit nie so maklik om dit alles onder een noemer tuis te bring nie. 
Verskillende terme word gebruik om hierdie taalgebruik te benoem. In die begrippepaar indikatief en imperatief, wat dikwels in die Homiletiek gebruik word, verwys die term imperatief byvoorbeeld hierna (kyk Floor, 1974:8; Labuscagne, 1981:1-5). In die Nuwe-Testamentiese wetenskap het die term paraenesel min of meer die status van ' $n$ geykte tegniese term vir hierdie saak gekry (kyk Koester, 1982:55-56; Stowers, 1986:23; Gammie, 1990:44).

In die eerste twee uitgawes van In die Skriflig is gedurende 1990 'n reeks artikels gepubliseer wat die verhouding tussen (soos in die artikels genoem) die "indikatief" en "paraklese" in die Nuwe Testament vanuit verskillende hoeke behandel. 2 In die reeks artikels word doelbewus teen imperatief en paraenese ten gunste van paraklese gekies (Venter, 1990:2). In hierdie artikel word die geldigheid van die artikelreeks se gebruik van die term paraklese ondersoek en word sekere insigte uit resente navorsing oor hierdie onderwerp nagegaan.

Ons argumenteer dat paraklese 'n term is wat moontlik gebruik kan word vir 'n subkategorie van die paraenetiese literatuur ${ }^{3}$ wat in die Nuwe Testament gevind word. Die aard van die moral exhortation (etiese appèl/aansporing/oproep ${ }^{4}$ ) in verskillende Nuwe-Testamentiese geskrifte word ondersoek, en daar word bevind dat deur die term van een moontlike sub-genre (naamlik paraklese) te gebruik as generiese term vir alle moral exhortation, daar nie aan die groot verskeidenheid binne die moral exhortation en

1 Verskillende konvensies bestaan vir die transliterasie van die Griekse woord rapaive oıs. In hierdie artikel word dic vorm paraenesis gebruik (met paraeneses as meervoudsvorm).

2 Een van ons (Van Rensburg) was decl van die proses wat tot dic publikasic van die artikels gelei het. Soos in 'n voetnoot by al dic artikels vermeld is, is dic artikels verwerkings van referate wat tydens ' $n$ winterskool vir predikante aangebied is. Die tema van die winterskool was "Die verhouding van indikatief en paraklese in dic Nuwe Testament". Die paradigmaticse artikel van dic reeks is dic van C.J.H. Venter: "Indikaticf en paraklese in die verkondiging met toeligting uit dic Pastorale Briewe" (1990:1-26), en faseltc daarvan (waaronder juis die deel waartcen in ons artikel dic stctkste kritick uitgespreck word) was die produk van die outeurs se voorafseminare. Die ander artikels is "Indikaticf en paraklese in Romeine" (M.A. Krüger, 1990:27-48); "Dic vcrhouding tussen indikatief en paraklese in die brief aan die Efesiers" (G.J.C. Jordaan, 1990:49-70); "Indikatief en paraklese in 1 Petrus en die implikasie daarvan vir die kerklike prediking vandag" (Fika J. van Rensburg, 1990:71101); 'Die verhouding tussen indikatief en paraklese in dic Nuwe Testament, toegclig vanuit dic cerste brief aan die Tessalonisense" (L. Floor, 1990:155-165).

3 Paraenetiese literatuur is 'n tegniese term vir 'n sckondêre genre wat nic in alle opsigte gelyk is aan paraenese nie. By dic behandeling van Gammie se taksonomic (\$3.3) word hicrdic onderskeidings verduidelik.

4 Etiese appel/aansporing/oproep is 'n poging om die icrm moral exhonation in Afrikaans weer te gee. Die Engelse term moral exhortation het in resentc navorsing (kyk Malherbe, 1986; Stowers, 1986; Perdue, 1990; Gammic, 1990) 'n spesifieke referensie- en konnotasiekader opgebou. Daarom word die Engelse term moral exhortation in hicrdic arlikel gebruik. 
die belangrike onderlinge verskille reg geskied nie. Vervolgens word die bekende term paraenesis as moontlike generiese term oorweeg, en ook nie geskik bevind nie. Paraenesis het in 'n tegniese sin 'n meer spesifieke verwysing, en laat dus ook nie reg geskied aan die verskeidenheid van moral exhortation in die Nuwe Testament nie.

Enkele belangrike uitgangspunte vir hierdie bespreking is die volgende:

- Die Nuwe Testament, as bundel dokumente wat in die eerste eeu ontstaan het, reflekteer noodwendig die literêre konvensies van die Hellenistiese wêreld. Vir die vasstelling van terminologie en onderskeidings oor genres/ sub-genres/vorme in die Nuwe Testament kan dus nie uitsluitlik net van die Nuwe-Testamentiese boeke gebruik gemaak word nie. 'n Studie van eersteeeuse Grieks-Romeinse literêre konvensies moet noodwendig berus op 'n breë basis van kontemporêre geskrifte.

- Die onderskeidings, kategoriee en terminologie soos voorgestel in antieke teoretiese geskrifte (soos gevind in teoretiese boeke oor die retoriek, epistolografie en literêre studie in die algemeen) kan waardevolle riglyne bied vir die bestudering van genres/vorme in die Nuwe Testament.

- Die etimologie van (enkel)woorde asook die moontlike betekenisse van

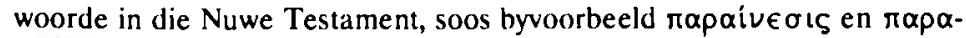
$k \lambda$ ń ıs, (selfs al word dit gedefinieer in terme van 'n semantiese veldteorie), het slegs beperkte waarde vir die identifisering en benoeming van literêre genres/vorme in die Nuwe Testament.

* Formele oorwegings (soos opvallende of herhalende grammatikale en/of sintaktiese konstruksies) asook die moontlike sosiale funksies wat die verskillende genres en sub-genres vervul het, moet ook in ag geneem word by die identifisering en tipering van sodanige literêre vorme.

Al hierdie uitgangspunte word later in die artikel beredeneer. In hierdie stadium net een opmerking oor die eerste uitgangspunt. Die (teologiese en kerklike) kriteria wat vir die vasstelling van die Nuwe Testament as dokumentebundel gegeld het, was nóg linguisties nóg literêr van aard. Die Nuwe Testament is nie 'n teoretiese handboek oor antieke literêre vorme en konvensies nie. Daarom kan die Nuwe Testament nie as die enigste bron vir die identifisering en benoeming van eerste-eeuse literêre konvensies wat in die Nuwe Testament gereflekteer word, gebruik word nie. Dit wil nou ook nie aan die ander kant weer sê dat die Nuwe Testament glad nie vir hierdie soort studie gebruik kan word nie. As een van meerdere antieke literêre geskrifte wat behoue gebly het, is dit wel verantwoord om die Nuwe Testament as ' $n$ bron van inligting te gebruik. 
Om verskeie redes is dit belangrik om in wetenskaplike werk noukeurig met terminologie om te gaan. Grondliggend aan wetenskaplike werk is die tref van onderskeidings en die benoeming van daardie onderskeidings. Verder is dit noodsaaklik dat 'n akademikus hom/haar nie terminologies uitfaseer uit die heersende wetenskaplike debat nie.

In hierdie artikel word begin met 'n evaluering van die gebruik van die term paraklese in die gemelde reeks artikels in In die Skriflig 1990 (kyk voetnoot 2). In die tweede helfte van die artikel word fasette van resente navorsing deur A.J. Malherbe (1986), S.K. Stowers (1986), J.G. Gammie (1990) en H.W Attridge (1990) oor NuweTestamentiese moral exhortation kortliks aan die orde gestel ten einde die geskiktheid van paraenesis as alternatiewe generiese term krities te beskou. In die lig daarvan word enkele gevolgtrekkings gemaak.

\section{2. 'N EVALUERING VAN DIE GEBRUIK VAN DIE TERM PARAKLESE}

Die sinopsis wat Jordaan (1990:50) gee van die uiteenlopende stelle terme wat in die navorsingstradisie gebruik gebruik word om die twee hoofdele wat in die briefliggaam van Efesiërs onderskei kan word, te benoem, is tiperend van die talle terme wat gebruik word. Hy noem die volgende: lofprysend/praktiese opdragte, belydend/vermanend, leerstellig/prakties, dogmaties/eties. liturgies/paranaeties, gebed/paraeneties. Alhoewel die moral exhortation in die Nuwe Testament dus 'n groot verskeidenheid vertoon en op verskillende maniere getipeer word, het 'n mens tog die aanvoeling dat daar iets gemeenskapliks in hierdie soort taalgebruik is. Die poging van die betrokke outeurs in In die Skriflig om 'n generiese term voor te stel, is dus te waardeer. Die geldigheid van die spesifieke term wat hulle voorstel, naamlik paraklese, is egter problematies. Die aannames en metodologie in terme waarvan hulle die term paraklese definieer, word vervolgens eksplisiet gemaak en geëvalueer.

\subsection{Die definiëring van paraklese}

Paraklese word gedefinieer as "die vermanend-bemoedigende aksie wat onlosmaaklik verbind is met en voortvloei uit die indikatief van die werk van God Drie-enig" (Venter, 1990:2-3).5 Kruger se definisie is "oproep, appel, bemoediging, troos en bevel" (1990:27). Hierdie definisie is baie ruim en omvat doelbewus meer as een betekenis. Dit is duidelik dat Kruger dit as generiese term vir alle soorte moral exhortation gebruik.

5 Venter (1990:2) noem in 'n voctnoot dat "die begrip paraklese meer indringend verklaar word deur Coetzee" in sy ongepublisecrde referaat wat gedurende die 1989-winterskool gelewer is. 
Van Rensburg definieer nie self die term paraklese nie, hy gebruik dit bloot. In 'n voetnoot aan die begin van sy artikel skryf hy egter dat sy artikel "veronderstel dat die leser ook die artikel van Venter wat as inleidende referaat tydens die kursus gedien het, gelees het" (1990:71). Floor (1990) doen min of meer dieselfde as Van Rensburg. Hieruit en uit Van Rensburg en Floor se gebruik van die term paraklese moet dus afgelei word dat hulle (en die ander deelnemers aan die winterskool) Venter se begripsomskrywing onderskryf.

\subsection{Motivering vir die gebruik van die term paraklese}

'n Belangrike motivering vir die gebruik van die term paraklese is dat daar sodoende aangesluit word "by die gebruiksveld van dié begrip in die Nuwe Testament" (Venter, 1990:2). Vir Kruger het die term "'n ruimer inhoud en laat [dit] beter reg geskied aan die inhoud van die Skrif wat in sy geheel appelerend inwerk op die lesers" (1990:28). Jordaan (1990:59) se belangrikste motivering vir hierdie keuse is die gebruik van die woord $\pi \alpha \rho \alpha k \alpha \lambda \dot{\epsilon} \omega$ "deur die skrywer self" aan die begin van die briefdeel en die rol

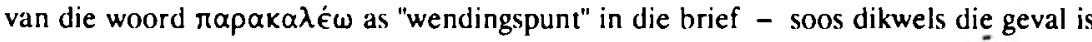
wanneer hierdie woord in Hellenistiese briewe gebruik word.

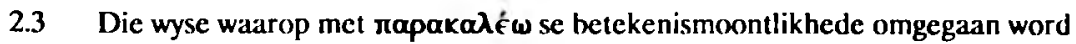

Venter (1990:2) vestig die aandag daarop dat Louw en Nida (1988) die gebruik van die woord $\pi \alpha \rho \alpha \kappa \alpha \lambda \epsilon \dot{\epsilon} \omega$ in, wat hy noem, vier "gebruiksvelde" onderskei. Vir die doeleindes van sy artikel fokus hy op "gebruiksveld een (om ernstig te versoek of te vermaan) en vier (om te bemoedig)" (1990:2). Hy motiveer nie waarom hy op slegs twee van die vier semantiese velde fokus en die ander twee ignoreer nie. Ter afsluiting van sy begripsomlyning van paraklese skryf hy die volgende:

Juis om te poog om reg te laat geskied aan die dubbele nuanse van vermaning en bemoediging, word hicr vir die begrip paraklese gekies. Saamgevat: vir die doelcindes van hierdie artikel word onder paraklese verstaan die vermanend-bemoedigende aksie wat onlosmaaklik verbind is met en voortvloei uit dic indikaticf van die werk van (God Drie-enig (1990:2-3).

Venter het hiermee duidelik gemaak met watter betekenis hy (en dus die ander winterskoolreferente - kyk voetnoot 2) die term paraklese gebruik. Die werkmetode roep egter verskeie vrae op.

- Die definisie van paraklese as "vermanend-bemoedigende aksie" laat die indruk dat hy nie die verskynsel van polisemie in ag neem nie. Die aanname 


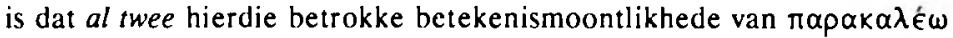
(vermaan én bemoedig) ter sake is in alle kontekste waarin hierdie woord gebruik word. Hierdie aanname is 'n voorbeeld van die praktyk van "illegitimate totality transfer" soos aangetoon deur James Barr (1961:218). 6 In sommige kontekste is slegs die betekenis "om dringend en met erns vir iets te vra" ( = om te smeek) ter sake (byvoorbeeld die papirus $B G U$ III.8467, 4 Makkabeërs 10:18, 2 Korintiërs 8:49 en Handelinge 28:2010). In ander kontekste is weer slegs die betekenis "om te veroorsaak dat iemand bemoedig of vertroos word" ter sake (byvoorbeeld Filippense 2:1 ${ }^{11}$ en Efesiërs 6:22 ${ }^{12}$ ). Verder is daar ook nog ander kontekste waar meer as een van hierdie betekenisse ${ }^{13}$ moontlik ter sake is (byvoorbeeld Ignatius Rom 7:2). Daar moet

6 'n Voorbecld ter illustrasic van illegitimate totality transfer: In Afrikaanse kan ten minste dric betckenismoontlikhede vir die woord leer onderskei word: (i) 'n hout- of metaalobjek wat 'n mens gebruik om op te $\mathbf{k l i m}$, (ii) die materiaal - velle van diere - waarvan onder andere skmene gemaak word, en (iii) 'n handeling wat die intellektuele aksic van kennisverwerwing aandui. In 'n sin soos "ek leer my wiskundestellings" is dic eerste en tweede betekenismoontlikhede glad nie ter sake nic; in 'n sin soos "ek staan op die leer en verf die plafon" is die tweede en derde glad nie ter sake nie en in die sin "die tas is van leer gemaak" is die ecrste en derde betckenisse nie ter sake nie. Wanneer die nie-tersaaklike betekenismoontlikhede in alle kontekste ingelecs word, is dit illegitimate totality transfer omdat die polisemieverskynsel geignoreer word.

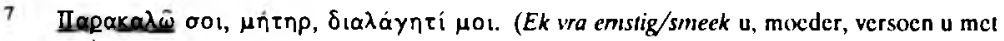
my.)

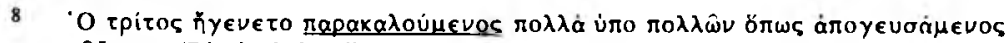

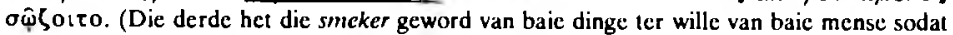
hy, nadat hy dit self geproc het, sou kon lewe.)

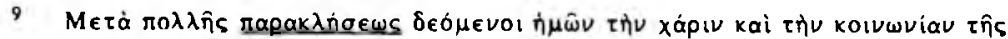

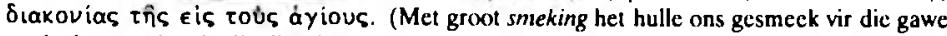
en deelgenootskap in die diensbetoning aan die heiliges.)

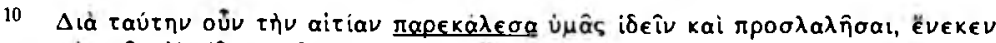

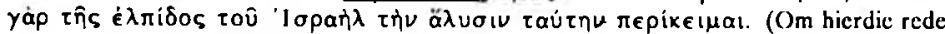
dus het ek emstig versoek/gesmeek om u te sien en toc te spreek, want dit is ter wille van die hoop van Israel dat ek met hierdic ketting geboei is.)

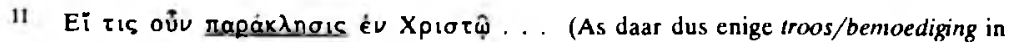
Christus is ...)

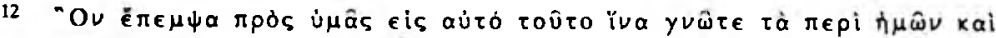

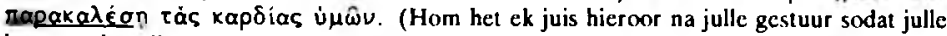
kan weet hoe dit met ons gaan en sodat hy julle harte kan vertroos.)

13 Daar is gevalle waar daar 'n saak uitgemaak kan word vir 'n gebruik van (of sinspeling op) meerdere verskillende betekenisse van dieselfde woord binne dieselfde kontcks. Die bekendste voorbeeld hiervan is ă $\nu \omega \theta \epsilon \nu$ in Johannes 3:3 (in dic gesprek lussen Jesus en Nikodemus), waar sowel dic betekenis weer as die betekenis van bo af gebruik word. Wendland (1990:313) gee ook ander voorbeelde van hicrdie verskynscl wat hy "semantic density" noem. Hy wys egter heel tereg daarop dat dit dic uitsondering is omdat daar 
dus in elke konteks bepaal word of die woord napak $\alpha \lambda \epsilon$ in die betrokke konteks die vermeende dubbele nuanse het of nie.

- Die term gebruiksveld laat nie reg geskied aan sommige van die belangrike linguistiese beginsels waarop Louw en Nida se woordeboek gebaseer is nie. Die definisies van die leksikale betekenisse van leksikale eenhede wat die woordeboek aangee, is nie sonder meer gelyk te stel met die kontekstuele gebruik van die betrokke eenhede nie. Daarom praat Louw en Nida konsekwent van semantiese velde en nie van gebruiksvelde nie. Sodoende tref hulle ook 'n duidelike onderskeid tussen semantiek (waarmee hulle hulle besig hou) en pragmatiek ('n ander sub-dissipline in die linguistiek wat op taalgehruik fokus) (kyk Leech, 1983:6 vir 'n bespreking van die verskil tussen semantiek en pragmatiek).

Jordaan (1990:60) noem as een van die begrondings van sy keuse vir die term paraklese

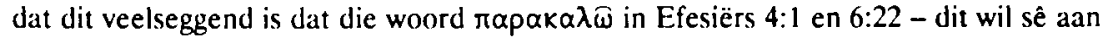
die begin en aan die einde van die tweede deel van die briefliggaam - voorkom. Hy konkludeer: "Die hele briefdeel word met die woord $\pi \alpha p \alpha k \alpha \lambda \in i v$ omvat en kan dus ook omvattend getipeer word as paraklese" (1990:60).

Die aanname grondliggend aan hierdie konklusie is problematies. 'n Literêre vorm kan immers nie geidentifiseer en getipeer word bloot op grond van betekenismoontlikhede van 'n enkele woord nie. Die woord $\pi \alpha \rho \alpha k \alpha \lambda \epsilon \dot{\epsilon} \omega$ word baie algemeen in antieke Griekse briewe gebruik en het 'n geykte plek en funksie as briefkonvensie gehad, naamlik as een van die formules warmee versoeke van allerlei aard gerig is. ${ }^{14}$ Enkele

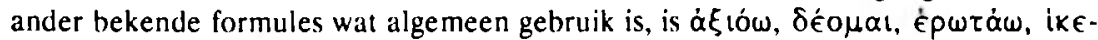

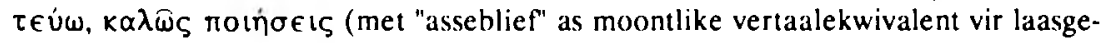
noemde term) (kyk Exler, 1923:116-123; Mullins, 1962:54; White, 1984:1736). As

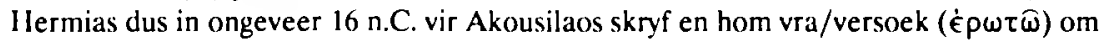
toe te sien dat Soterichos nie uitgebuit word deur die persoon wat die stuk grond aangrensend aan syne gekoop het nie ( $P$ Tebt II.410), kan die aard van hele tweede helfte van sy brief dan bestempel word as 'n 'erotiese' gedeelte in die brief en die inhoud daarvan as 'erotase'? As Theon ongeveer in die jaar 25 n.C. in 'n brief die

normaalweg slegs een betckenis van 'n woord met meerdere betekenisse in 'n spesifieke konteks gebruik word (1990:303-304). Dit is 'n saak waaroor daar in clke geval en in elke konteks opnuut 'n besluit genecm moel word.

14 Bywoorbecld in P Par 42, BGU IV.1141, P Oxy IV.744, P Oxy VIl. 1061, P Amh II.130, $P$ Oxy 1.117, $P$ Lond 1244, Aristeas 229, 235, BGU I.248; kyk Moulton \& Milligan, 1974:484. 
dioketos Tyrannos versoek ( $\pi \alpha \rho \alpha \kappa \alpha \lambda \omega$ ) om sy broer Herakleides as "aanbeveel"15 te beskou (P Oxy II.292), moet dit bestempel word as 'n 'parakletiese gedeelte' in die brief en die inhoud 'paraklese' genoem word? So kan ons aangaan en die exhortationgedeeltes in verskillende briewe aksio-ose, deo-ose, iketeuse, kaloos poiese, ensovoorts, begin noem. In die geval van die Nuwe Testament moet Filippense 4:316 en 1 Tessalonisense 5:12-1317 dan bestempel word as erotase, Hebreërs 5:718 as iketeuse en/of deo-ose, Romeine 1:1019 as deo-ose en (soos Jordaan wil) Efesiërs 4:1-6:22 as paraklese. In sommige van die kontekste wat so pas genoem is, word verskillende

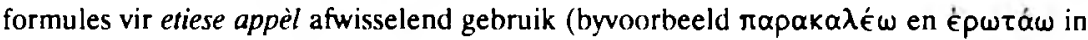
Filippense 4:2-3) - watter formule moet dan voorkeur geniet in die benoeming van die betrokke briefdeel en op watter gronde kan so 'n besluit geneem word?

Die probleem is duidelik: om slegs bepaalde woorde (selfs al word dit binne geykte formules herhaaldelik gebruik) te gebruik om die inhoud, aard en literêre vorm van antieke briefdele te tipeer, is meer verwarrend as verhelderend indien dit konsekwent so gedoen word.

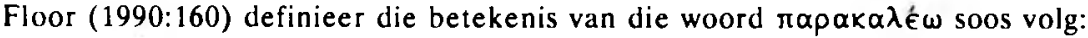
"r $\alpha \rho \alpha \kappa \alpha \hat{\lambda} \omega$ kan beteken: versoek, vermaan, vertroos, maar die grondbetekenis van hierdie werkwoord is herbeiführen" (ons beklemtoning). As begronding van hierdie

15 Dic vertaling aanbeveel laat nic volle reg geskied aan die tegniese term vir die commendatory

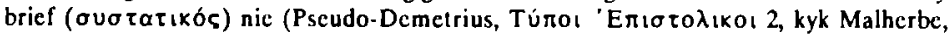
1988:32). Dit was praktyk om deur middel van briewe persone by belangrike ampsdracrs of ryk mense bekend te stel sodat die cen wat aanbeveel of bekend gestel word bepaalde voordele (byvoorbeeld werksgeleentheid of hulp mel 'n reis, el cetera) kan ontvang (kyk Kim, 1972).

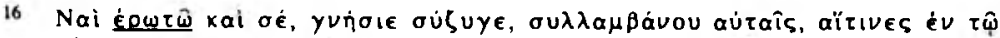

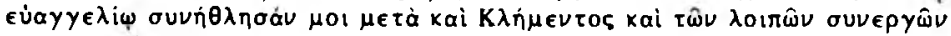

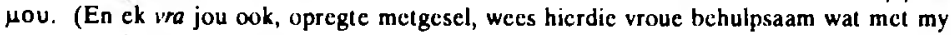
saamgestry het in die evangelie.)

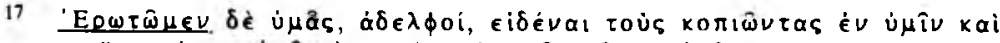

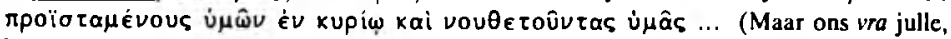
broers, erken die wat onder julle arbei en julle voorgangers in die Here is en julle vermaan ...)

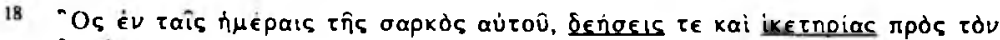

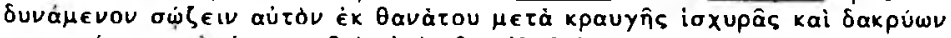

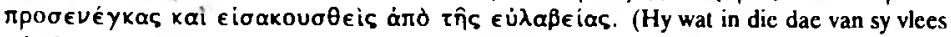
gebede en smekinge tot Hom wat in staat is om te red uit die dood met sterk geroep en trane geoffer bet en verhoor is uit angs.)

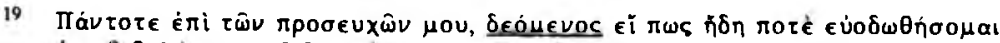

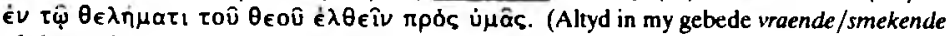
of ck tog nie cindelik 'n goeie geleentheid sal vind om deur die wil van God na julle te kom.) 
definisie volstaan hy met 'n verwysing na Schmidz se artikel in die TWNT. Hierdie stelling is in twee opsigte problematies: is die drie verskillende betekenisse (wat

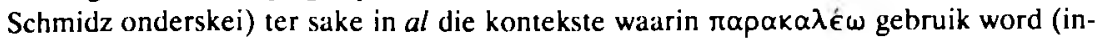
dien wel, is hier nogeens 'n geval van illegitimate totality transfer), of is slegs die 'grondbetekenis' orals ter sake? Wat is 'n grondbetekenis en hoe stel 'n mens dit vas? Die probleme met die idee van 'n grondbetekenis vir woorde wat meerdere verskillende betekenisse kan hê (polisemie) is immers breedvoerig en oortuigend in die semantiek en ook in die Bybelwetenskappe aangetoon (kyk Barr, 1961:107 e.v. oor wat hy "root fallacy" noem; kyk ook Louw, 1982:23-37; Silva, 1983:44-51; en Carson, 1984:26-32). Floor maak egter geen spesifieke afleidings uit sy opmerkings oor die term paraklese as aanduiding van 'n literêre vorm na aanleiding van sy definisie van die betekenis van $\pi \alpha \rho \alpha \kappa \alpha \lambda \epsilon ́ \omega$ nie. Daarom hoef daar vir die doel van hierdie artikel nie verder op die saak ingegaan te word nie.

\section{Spesifiek homiletiese of spesifiek Nuwe-Testamentiesc (vak)terminologie}

Venter stel dit dat hy in die plek van die begrippe indikatief en imperatief wat "normaalweg in teologiese literatuur gebruik word", vir die doel van sy artikel die terme "indikatief" en "paraklese" gebruik (1990:2). Hy praat in die algemeen van "teologiese literatuur" en maak nie onderskeid tussen terminologie wat meer spesifiek in die Homiletiek gebruik word en ander wat weer meer spesifiek in die Nuwe-Testamentiese wetenskap gebruik word nie. Aangesien elke vakwetenskap sy eie referensiekader en stel konnotatiewe betekenisse rondom bepaalde terminologie opbou, is dit egter verkieslik dat vakterme nie sonder goeie motivering uitruilbaar gebruik word nie.

\subsection{Die uitruilbaarheid van paraklese met ander terme}

\subsubsection{Uitruilbaar vir protrepsis, paraenesis en diatribe}

Die wyse waarop Venter (1990:2) Malherbe (1986:122-134) se bespreking van drie stylsoorte van moral exhortation, naamlik protrepsis, paraenesis en diatribe ter ondersteuning van sy definisie van $\pi \alpha \rho \alpha \kappa \alpha \lambda \epsilon \in \omega$ gebruik, skep die indruk dat paraklese vir Venter op presies dieselfde neerkom as protrepsis en/of paraenesis en/of diatribe.

Ook Krüger gebruik die terme paraenesis/paraklesis volledig uitruilbaar. Dit blyk daaruit dat hy dit wat Venter (1985) aangaande paraenesis in Romeine 12:1-15:13 skryf, gebruik vir dit wat hyself "paraklese" noem (kyk Kruger, 1990:39). Verder gebruik ook Floor (1990) hierdie terme uitruilbaar. Dit blyk onder andere wanneer hy 
(1990:157) dit wat ander outeurs oor paranetiese materiaal sê, van toepassing maak op wat hy as paraklese beskou.

Jordaan (1990:59) sien egter 'n duidelike verskil tussen paraenese en paraklese; laasgenoemde gaan verder as eersgenoemde: "Met die woord $\pi \alpha p \alpha \kappa \alpha \lambda \omega \widehat{\omega}$ word egter aangedui dat die skrywer meer as 'n paraenese gaan aanbied. In plaas van 'n blote lys moets en moenies, gaan die skrywer 'n paraklese aan sy lesers gee, dit wil sê 'n vermaning met besondere intimiteit en vertroue" (1990:59). Dit is 'n insiggewende opmerking maar ongelukkig deurstaan dit nie die toets van 'n kritiese analise van die gebruik van die terme in die antieke literatuur nie (kyk $\$ 3$ hieronder).

\subsubsection{Uitruilbaar vir exhortation}

Nadat Van Rensburg (1990:74-80) na verskeie persone se werk in sy bepaling van die stand van navorsing ten opsigte van 1 Petrus verwys het - waarvan nie een die term paraklese gebruik nie - skryf hy: "Navorsers is dit eens dat die brief hoofsaaklik parakleties van aard is" (1990:80, ons kursivering). Ter begronding van hierdie stelling verwys hy na die opmerking van Stowers (1986:96) dat "exhortation" 'n groot rol in 1 Petrus speel en Stowers se tipering van die brief as "a complex hortatory letter". Van Rensburg stel dus paraklese gelyk aan exhortation.

\subsection{Uitruilbaar vir imperatief}

Venter (1990:3-9) gee 'n oorsig oor enkele aspekte van die navorsingstradisie in die Nuwe-Testamentiese wetenskap, die etiek, pastoraal en homiletiek met betrekking tot "die indikatief en die paraklese in die verkondiging". Onder die opskrif "Paraklese" bespreek hy egter gewoon dit wat in verskeie teologiese subdissiplines onder die term imperatief gedoen is. In die samevatting aan die einde van hierdie oorsig (1990:8-9) gebruik hy konsekwent die term imperatief en nèrens die term paraklese nie, maar in die slotsom van sy artikel (1990:24) praat hy van die "huidige stand van navorsing oor die funksionering van indikatief en paraklese in die teologie." Nie een van die outeurs wat hy aan die orde stel, gebruik egter self die term paraklese nie. Venter (1990:3) sè wel in 'n voetnoot "waar outeurs in literatuur die terminologie indikatief en imperatief gebruik, word in die weergawe en beoordeling van hulle standpunte by hulle terminologie gehou". Hy gebruik die terme imperatief en paraklese dus uitruilbaar. Floor volg hom hierin na wanneer hy byvoorbeeld in sy afdeling "Die koppeling van indikatief en paraklese" (1990:157-159) die term paraklese nie net met imperatief uitruil nie, maar ook met die terme etiek en lewe. Kruger (1990:28) verwerp die terminologie indikatief en imperatief, en wel om twee redes: met "imperatief" word die 
klem makliker geplaas op "n wettiese houding waar bevele gehoorsaam moet word" en omdat "die vader-kindverhouding" as gevolg hiervan "te min beklemtoon word."

Die vraag ontstaan dus waarom 'n nuwe term paraklese daargestel word as dit in praktyk niks anders sê as dit wat in die navorsingstradisie met die term imperatief gesê word nie.

\subsubsection{Uitruilbaar vir opdrag}

Van Rensburg gebruik in sy artikel soms die term paraklese (1990:80, 85, 86, 96-100), een keer die neutrale formulering die "indikatief-gedeelte en die res van die brief" (ons kursivering) (1990:85), en soms praat hy gewoon net van "opdragte" (1990:86-90). Verder is reeds hierbo (\$2.5.2) aangetoon dat hy paraklese en exhortation skynbaar as sinonieme gebruik. Dit blyk nou verder dat paraklese/exhortation vir hom ekwivalent is aan opdragte.

Die gebruik van die term opdrag veronderstel 'n hiërargiese gesagsverhouding en dit het veral in Afrikaans konnotasies (bv. klinies, rigied) wat dit ' $n$ minder geskikte term maak om die toonaard van die moral exhortation" van 1 Petrus (en ander NuweTestamentiese briewe) weer te gee.

\subsection{Meerdere uitruilbaarheid}

Uit die bostaande blyk die meerdere uitruilbaarheid duidelik. Die volgende formulering van Floor (1990:158) is tiperend van die hoë graad van uitruilbaarheid van die term paraklese: "Die oorgangspartikel het dus 'n brugfunksie. Op hierdie wyse word die oorgang van die indikatief na die paraklese, van die dogmatiek na die etiek, van die leer na die lewe gemaak." Al hierdie terme kom vir Floor kennelik op min of meer dieselfde neer.

\subsection{Gevolgtrekking}

Algemene tendense en gedeelde uitgangspunte wat in die reeks paraklese-artikels onderskei kan word, is die volgende:

- Die term paraklese word as 'n generiese term gebruik waaronder alle vorme, style en inhoude van moral exhortation in die Nuwe Testament tuisgebring word. 
- Vir die definiëring van die term paraklese word slegs die Nuwe Testament as studie-objek en vergelykingsbasis gebruik.

* Die definiëring van paraklese berus op betekenismoontlikhede van die

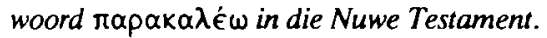

* Op grond van bekende linguistiese beginsels kan die wyse waarop met die

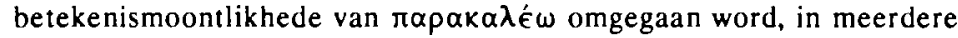
gevalle ernstig bevraagteken word.

* Die uitruilbaarheid van paraklese met terme soos imperatief, paraenesis, opdragte, exhortation en etiek, bevestig enersyds die wye referensiekader wat aan die term paraklese toegeken word en laat andersyds die vraag ontstaan waarom daar dan enigsins ' $n$ nuwe term geskep is.

- Behalwe Van Rensburg20, en in 'n mindere mate Jordaan, werk die outeurs hoofsaaklik 'inhoudelik', met weinig oog vir die literêre konvensies, genres en vorme van die eerste-eeuse Grieks-Romeinse samelewing en die oorwegings wat by die identifisering en benoeming daarvan ' $n$ rol kan speel.

Soos vroeër gestel, word die winterskoolreferente se poging om 'n generiese term vir moral exhortation in die Nuwe Testament voor te stel, waardeer. Dit hou verband met 'n belangrike resente navorsingstendens: onder leiding van A.J. Malherbe (Yale Divinity School) is daar in 1990 'n studiegroep in die Society of Biblical Literature gestig met "Hellenistic Moral Philosophers and the New Testament" as tema. 'n Aktuele en belangrike probleem word dus onder die loep geneem. Uit die bostaande blyk dit egter dat die voorgestelde term paraklese nie vir hierdie doel geskik is nie. Die aannames en metodologie in terme waarvan hulle die term definieer, is veral problematies, en ook die feit dat hulle werk nie koherent is nie en hulle nie konsistent in terme van hulle onderskeidings werk nie.

In die tweede gedeelte van hierdie artikel word vervolgens enkele fasette van die werk wat in die jongste tyd rondom die terminologie vir moral exhortation gedoen is, aan die orde gestel. Die doel van hierdie bespreking is om die geskiktheid van die term paraenesis as generiese term vir moral exhortation in die Nuwe Testament te ondersoek. Dit word gedoen in die lig van die uitgangspunte wat aan die begin van hierdie artikel gestel is.

20 Van Rensburg (1990:71-74) begin sy artikel met 'n uiteensetting van enkele rescnte navorsingsresultate rondom die literêre, retoriese, vormkriticse en tematiese aspckte van NuwcTestamentiese briewe in die algemeen 'n uiteensetting wat hy grootliks baseer op die boek van David Aune The New Testament in Its Literary Environment (1987). 
3. FASETTE VAN RESENTE STUDIES OOR NUWE-TESTAMENTIESE MORAL EXHORTATION

\subsection{A.J. Malherbe}

'n Belangrike uitgangspunt vir Malherbe se boek Moral Exhortation. A Greco-Roman Sourcebook is dat die moral teaching van die vroeë Christene (insluitende die Nuwe Testament en die Apostoliese Vaders) in baie opsigte ooreenkomste vertoon met dié van hulle nie-Christelike tydgenote, en grootliks deur dié tydgenote beïnvloed is (1986:11). Die doel van sy boek is om sekere passasies uit die geskrifte van GrieksRomeinse moral philosophers wat hierdie invloed illustreer, byeen te bring en in vertaling beskikbaar te stel. Daarom noem hy dit 'n sourcebook. Hy bring 'n wye verskeidenheid van tekste van Platoniste, Peripatetici, Stoisyne, Sinici, Epikureërs, Pythagoriane en Skeptici bymekaar. Die tekste word onder 'n aantal temas saamgegroepeer en by elke tema gee Malherbe 'n baie insiggewende inleiding. So byvoorbeeld behandel hy die sosiale kontekste waarin moral exhortation gegee is (1986:23-29), die doelwitte en aard van die moral teacher (1986:30-47), die wyses waarop te werk gegaan is om moral teaching te gee - naamlik toesprake, briewe en epitomes (1986:68120), die verskillende style van exhortation (1986:121-135), die literêre en retoriese konvensies rondom moral exhortation (1986:135-143) en laastens 'n aantal algemene onderwerpe (topoi) wat die inhoud van hierdie exhortation uitgemaak het (1986:144. 162).

Dit is dus duidelik dat Malherbe die praktyk van moral exhortation in die GrieksRomeinse eras rondom die ontstaan van die boeke van die Nuwe Testament oor 'n baie wye spektrum illustreer. Onder elke onderwerp toon hy moontlike verbande met Nuwe-Testamentiese en ander vroeg-Christelike geskrifte aan. Hy is versigtig om nie te reglynig verbande te lê nie en wys spesifiek daarop dat daar somtyds baie noue parallelle is en ander kere nie (1986:15). Die volgende opmerking van Malherbe (1986:14-15) is vir die onderwerp onder bespreking van besondere belang:

As the pagan matcrial does not represent a scamless whole, so does not the Christian material to which reference is made ... The diversity in ethical outlook within the Christian matcrial is well-known; here it needs to be added that Christian attitudes toward pagan morality were equally complex. On the one hand, they regarded their pre-Christian pagan lives as a morass from which they were thankful to have been delivered (cf. 1 Cor. 6:9-11; Eph. 2:1-2; Titus 3:3; 1 Peter 1:18) and to which they were now superior (ef. 1 Cor. 5:1; 1 Thess. 4:5). On the other hand, by urging that Christian behaviour would bring honour to God and respect to the faith and the faithful, they presupposed an agreement with the standards of their socicty (cf. 1 Cor 10:32; Col. 4:5; 1 Thess. 4:12; 1 Tim. 3:7; 6:1; Titus 2:5,8,10; 1 Peter 2:12, 15; 3:1, 16; 1 Clem. 1.1; 47.7; Ignatius Trall. 8.2). Furthermore, some Christian writings - for example, the pastoral epistles are more closely related to the Greco-Roman moral tradition than others. 
Die doel van hierdie uitvoerige aanhaling is om die spektrum en uiteenlopendheid van sowel die nie-Christelike as die Christelike tradisies en praktyke van moral exhortation te onderstreep. Die nie-Christelike filosofiese skole en geskrifte was dus nie bloot net dooie 'dékor' wat gedien het as 'agtergrond' waarteen die Nuwe Testament afgespeel het nie. Alles het deel gevorm van 'n groot dinamiese geheel met ingrypende onderlinge verskille en beïnvloeding. Juis dit illustreer ook waarom dit nie so maklik is om al die fasette van Nuwe-Testamentiese moral exhortation onder een generiese term tuis te bring nie.

In sy bespreking van stylsoorte van moral exhortation, behandel Malherbe (1986:121134) agtereenvolgens protrepsis, paraenesis en diatribe en illustreer elke styl met passasies uit die nie-Christelike literatuur.

Hy (1986:122) definieer protrepsis as 'n styl van moral exhortation

designed to win over someone to a particular enterprise of way of life by demonstrating its superiority ... Protrepris then continued to enlist recruits for the philosophical enterprise itself or for the the moral life grounded in and guided by philosophy.

Volgens hom is daar geen voorbeelde van protrepsis in die Nuwe Testament self nie, maar is dit 'n verskynsel wat eers in tweede-eeuse Christelike geskrifte verskyn (byvoorbeeld in die Brief aan Diognetos) (1986:122).

Malherbe (1986:124-125) noem sewe formele en algemene kenmerke van paraenesis en gee in elke geval voorbeelde daarvan in Christelike literatuur:

- Die inhoud daarvan is tradisioneel en nie nuut nie, soos aangedui deur die frase "soos julle weet" ( 1 Tessalonisense $1: 5 ; 2: 2,5 ; 3: 4$ ).

* Paraenesis is algemeen toepasbaar (alhoewel dit nie beteken dat dit nie ook soms aangepas is by die spesifieke kontekste waarin dit gebruik is nie).

* Aangesien dit wat aanbeveel word reeds bekend is, word verdere instruksie dikwels onnodig geag (2 Korintiërs 9:1; 1 Tessalonisense 4:9; 5:1).

* Die lesers/hoorders word bloot net herinner aan wat hulle reeds weet (1 Tessalonisense $2: 9 ; 3: 6$ ).

* Die lesers/hoorders word dikwels gekomplimenteer met wat hulle reeds besig is om te doen (1 Tessalonisense 4:1,10; 5:11; Ignatius Polycarpus 1.2; Ignatius Efesiërs 4.1). 
* Die lesers/hoorders word aangemoedig om aan te hou met wat hulle doen (1 Tessalonisense 4:1,10).

* Om die paraenetiese exhortation konkreet te maak, word dikwels 'n voorbeeld vir navolging voorgehou (Handelinge 20:31-34; 1 Tessalonisense 1:6; 2 Tessalonisense 2:1-8; 1 Korintiërs 4:14-17).

* Paraenetiese exhortation kan bestaan uit 'n reeks kort admonitions (Romeine $12 ; 13$ ) of dit kan in meer uitgebreide vorm gegee word (Jakobus 2,3; Hermas).

Laastens bespreek Malherbe die diatribe. Hy definieer dit as "essentially a popular philosophical treatment of an ethical topic and has the practical aim of moving people to action rather than reflection" (1986:129). As voorbeelde van diatribes in die Nuwe Testament noem hy 1 Korintiers 15:35; Romeine 9:19; Jakobus 2:18 en etlike ander (1986:129-130).

Malherbe self gebruik nêrens die term paraklese om enige faset van moral exhortation te tipeer nie. Die aandag is reeds daarop gevestig dat hy daarin slaag om die wye spektrum van inhoud, stylsoorte en kontekste van moral exhoration te illustreer. Uit die verskille wat Malherbe tussen protrepsis, paraenesis en diatribe aantoon, word dit duidelik dat ook die term paracnesis nie as generiese term vir alle soorte moral exhortation geskik is nie.

\subsection{S.K. Stowers}

Die fokus van Stanley K. Stowers se boek, Letter-writing in Greco-Roman Antiquity (1986) is spesifiek op die teorie en praktyk van briefskryf gerig en nie op moral exhortation as sodanig nie. Stowers se werk verteenwoordig in drie opsigte 'n belangrike nuwe fase in die studie van antieke briewe:

* Hy gaan uit van 'n basiese opvatting dat briewe beskou moet word as sosiale handelinge wat in terme van die Grieks-Romeinse samelewingskonvensies geïnterpreteer moet word (1986:16).

- Hy bestudeer die Nuwe-Testamentiese briewe in vergelyking met 'n hele spektrum van briewe, insluitende sowel die briewe wat voorkom in die dokumentêre papiri as die meer 'literêre' briewe (van byvoorbeeld Epicurus, Cicero, Seneca, Plinius, Basilius, Hieronymus, die Brief aan Diognetos, Julianus en ander (1986:23)). 
- Hy integreer die insigte van antieke briefteoretici en retorici in sy teoretiese beskrywing van brieftipes, briefvorme en brieffunksies (1986:23). Veral Pseudo-Demetrius en Pseudo-Libanius se teoretiese beskrywings van brieftipes en briefstyle speel 'n belangrike rol in die tipologie en terminologie wat Stowers voorstel.

Een van die ses hooftipes antieke briewe wat Stowers in terme van hierdie uitgangspunte identifiseer, is "Letters of Exhortation and Advice" (1986:91-152). Vir sy teoretiese beskrywing van hierdie brieftipe maak hy grootliks gebruik van Isokrates se Aan Nikokles en van Aristoteles se Protreptikos. Hierdie hoofgroep verdeel hy in die volgende ses sub-groepe: 21

" "Paraenetic letters" (byvoorbeeld 1 Tessalonisense; 1 Korintiërs 3:5-4:21; 2 Timoteus; 1 Petrus; Jakobus; Seneca Brief 6.5; Plinius Brief 2.6; Augustinus Brief 210).

" "Letters of Advice" (symbouleutikai) (byvoorbeeld 1 Korintiërs 1-4; 2 Korintiërs 8-9; Plinius Brief 7.1).

- "Protreptic letters" (exhortation to a way of life) (byvoorbeeld Romeine; Epicurus Aan sy moeder; Epicurus Aan Menoeceus; die Brief aan Diognetos).

- "Letters of Admonition" (nouthetetikai) (byvoorbeeld Kolossense 3:16; 1 Korintiërs 5-6; Plinius Brief 9.12; Basilius Brief 262).

" "Letters of Rebuke" (byvoorbeeld Galasiërs; 2 Korintiërs 10:1-12; Seneca Brief 99; Basilius Brief 2).

" "Letters of Reproach" (oneidistikai) (byvoorbeeld Diogenes Brief 28).

" "Letters of Consolation" (paramuthetikai) (byvoorbeeld 1 Tessalonisense 4:13-18; Gregorius van Nazianze Aan Gregorius van Nyssa; Basilius Brief 5).

Stowers gee benewens hierdie (en nog baie ander) voorbeelde in sy behandeling van elkeen van hierdie sub-tipes ook 'n teoretiese bespreking en definisie van elk. So byvoorbeeld onderskei hy tussen paraenesis en protrepsis in briewe op grond van die verskil in die aard van die lesers/gehoor wat deur elk veronderstel word: protrepsis

21 Die Engelse en Grickse terminologie word doelbewus behou. 
roep die lesers/hoorders op tot 'n nuwe en ander lewenswyse, en paraenesis roep die lesers/gehoor op om aan te hou met 'n sekere lewenswyse waarmee hulle reeds besig is (1986:92). Anders as Malherbe wat geen voorbeelde van protrepsis in die Nuwe Testament vind nie, maak Stowers 'n sterk saak daarvoor uit dat Paulus se brief aan die Romeine protrepties is.

Rondom paraenesis, wat vir die onderwerp onder bespreking spesifiek van belang is, maak Stowers (1986:23) die volgende belangrike algemene opmerking:

Scholars have understood paraenesis as the giving of miscellancous moral precepts and admonitions. The idea that Paul's letters have paraenetic sections before their conclusions is not substantiated by the letters themselves and reflects a misunderstanding of what paraenesis is. Paraencsis has been too narrowly understood in New Testament studies. It is not just the stringing together of traditional precepts and exhortations. A whole paraenetic or honalory tradition of rhetoric developed in antiquity [ons kursivering]. Paracnesis includes not only precepts but also such things as advice, supporting argumentation, various modes of encouragement and dissuasion, the use of examples, models of conduct, and so on.

Hierdie waarneming van Stowers onderstreep die opmerking wat reeds vroeër na aanleiding van Malherbe se werk gemaak is, naamlik dat ook die term paraenesis nie sonder meer as generiese term vir alle (moral) exhortation in die Nuwe Testament gebruik kan word nie.

Die enkele flitse van die werk van Stowers wat hier weergegee is, illustreer opnuut die groot verskeidenheid van style en wyses waarop moral exhortation by wyse van briewe gegee is. Dikwels pas dieselfde gedeeltes (byvoorbeeld 1 Korintiërs 1-4) onder meer as een van hierdie sub-tipes in. Stowers self gebruik nêrens die term paraklese nie, waarskynlik omdat dit nie voorkom in die antieke epistolografiese en retoriese bronne wat hy vir die vasstelling van sy terminologie en tipologie gebruik het nie.

\section{$3.3 \quad$ J.G. Gammic}

Waar sowel Matherbe as Stowers 'n breër fokus in hulle boeke het (soos aangetoon in \$3.1 en 3.2), fokus die artikel van Gammie spesifiek op paraenesis: "The present essay focuses on Paraenesis as 'form'. My interests here are taxonomic. That is, I attempt to define and locate Paraenesis as a literary genre or type" (1990:41). Vir die onderwerp onder bespreking is Gammie se artikel dus direk van toepassing.

Gammie gebruik 'n baie wye vergelykingsbasis op grond waarvan hy 'n taksonomie vir "Paraenetic literature" (wat hy 'n "secondary genre" noem) voorstel: hy gebruik tekste vanaf die antieke Midde-Oosterse wêreld (Egipte, Sumerië en Babilonië) tot by die Mediterreense wêreld van die Romeinse Ryk. Op grond van 'n noukeurige ondersoek 
van literatuur oor hierdie geweldige wye spektrum, stel Gammie die volgende taksonomie vir Paraenetiese literatuur voor:

Gammie: Toward the Morphology of a Secondary Genre

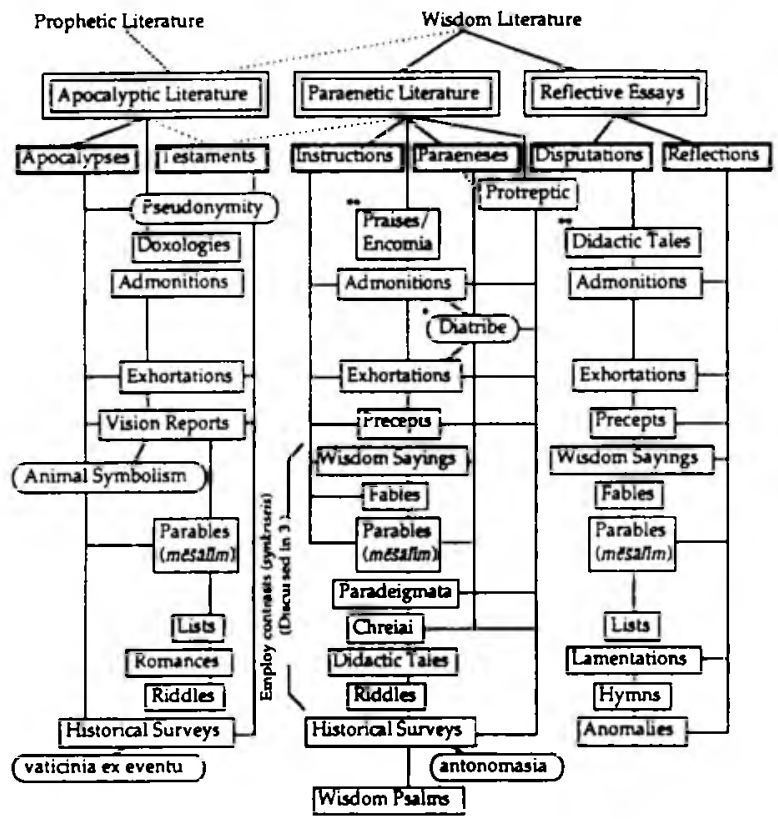

The Secondary Genres of Wisdom Literature

\section{Legend}

$\begin{aligned} \square & =\text { usual component } \\ & =\text { possible component } \\ & =\text { device rather than sub-genre } \\ & =\text { Secondary Genres } \\ & =\text { Composite Sub-genre (Divisions) } \\ & =\text { Sub-genre } \\ & =\text { May utilize form of the letters } \\ & =\text { Serve as traming sub-genres }\end{aligned}$


Indien al hierdie terme en die verskille tussen hulle hier verduidelik moet word, sal dit daarop neerkom dat Gammie se omvattende en hoogs tegniese artikel feitlik heeltemal oorgeskryf moet word. Daarom word daar volstaan met ' $n$ verduideliking van sy basiese onderskeidings en die aantoon van algemene tendense.

Dit is in die eerste plek belangrik om te let op die onderskeid tussen primêre literêre genre (Wysheidsliteratuur), sekondêre literêre genre (Paraenetiese literatuur) en subgenre (paraenesis). Dit is volgens Gammie (1990:45) baie misleidend wanneer een sub-genre toegelaat word om die hele veld te dek (asof daar byvoorbeeld geen ander soort profetiese literatuur as oordeelsprofesie is nie - terwyl sowel oordeelsprofesie as heilsprofesie profetiese literatuur is). Onder die sekondêre genre 'Paraenetiese literatuur' onderskei hy tussen Instructions (sy Engelse ekwivalent vir die Egiptiese term ma' at) en Paraeneses as saamgestelde sub-genres. (Paraeneses as saamgestelde sub-genre is dus nie ekwivalent aan die sekondêre genre Paraenetic literature nie.) Volgens Gammie (1990:51) moet die onderskeid tussen Instructions en Paraeneses op dieselfde wyse getref word as die onderskeid tussen 'n orkaan ('n storm in die Karibiese See) en 'n tifoon ('n storm in die Oos-Asiatiese Stille Oseaan). Die verskynsel waarna die twee terme verwys, kom dus grootliks op dieselfde neer, met die verskil dat Instructions dui op die antieke Egiptiese, Sumeriese, Babiloniese (en ook Ou-Testamentiese) moral instruction, terwyl Paraenesis op die Grieks-Romeinse moral instruction dui. Uit die skematiese voorstelling van sy taksonomie word dit verder duidelik dat admonitions ${ }^{22}$, exhortations ${ }^{23}$, precepts ${ }^{24}$, wisdom sayings en parables (mesalim) sub-genres is wat in albei die saamgestelde sub-genres (Instructions en Paraeneses) voorkom. Paradeigmata ${ }^{25}$ en Chreiai ${ }^{26}$ is egter sub-sub-genres wat eerder in die Grieks-Romeinse tradisie van Paraenesis gevind word as in die Egiptiese (en ander Midde-Oosterse) Instructions.

Die belangrikste waarneming wat vir die doel van hierdie bespreking uit Gammie se taksonomie gemaak kan word, is dat die term paraenesis (waaronder noukeurig onder-

22 Gammie (1990;67) definieer dit as: "(Mahnungen or Mahnwörer, lit. "warnings" or "words of warning"). Sub-genres or species aimed at dissuasion."

23 Gammic (1990:69) definicer dit as: "Sub-genres of each of the three main branches of rhetoric, as well as of Paracnetic Rhctoric and Litcrature, in which the addressec is invited, cncouraged, directed or commanded to persue a given course of action or to adopt a given attitude."

24 Gammie (1990:70) definicer dit as: "Sentences, usually phrased in the indicative mood, which instruct and contain an implicd or obvious directive for conduct."

25 Gammie (1990:70) definieer dit as: "Models, illustrations, examples."

26 Gammic (1990:68) definicer dit as: "Frequently instructive ancedotes of action or speech aptly attributed to a particular person." 
skei moet word tussen die gebruik van die term as sekondêre genre en as saamgestelde sub-genre), 'n hele spektrum van literêre konvensies of sub-genres verteenwoordig. Die onnoukeurigheid daarvan om alle Nuwe-Testamentiese moral exhortation onder net die term paraenesis tuis te bring, word hiermee opnuut bevestig.

Gammie se taksonomie is baic nuttig om die term paraenesis en die kompleksiteit daaraan verbonde uit te rafel. Dat sy poging egter nie in alle opsigte suksesvol is nie, word oortuigend aangetoon deur Attridge (1990) en Robbins (1990). Robbins (1990: 262) kritiseer veral die kriteria in terme waarvan hierdie taksonomie saamgestel is, naamlik uitsluitlik formele literêr-historiese oorwegings wat uitsluitlik op grammatikale en sintaktiese analise berus. Hy redeneer dat indien die sosiale kontekste waarin moral exhortation gegee is, in ag geneem word, die verskynsel meer bevredigend beskryf kan word (1990:263). Attridge bring ook geldige kritiek teen Gammie se onderskeid tussen paraenesis en protrepsis in (1990:213).

Dit is egter op ' $n$ ander vlak wat Attridge se artikel vir ons doel belangrik is: hy wys daarop dat Gammie se taksonomie nêrens voorsiening maak vir moral exhortation wat by wyse van ' $n$ homilie ('n preek) gegee is nie. Om hierdie leemte te ondervang, stel Attridge die term paraklese as verdere sub-genre van paraenetiese literatuur voor (1990:216). Daar word dus vervolgens kortliks op Attridge se bydrae ingegaan.

\section{$3.4 \quad$ H.W. Attridge}

Attridge (1990:215-216) toon aan dat 'n baie opvallende vorm (bestaande uit 'n introduction, citation, expository development, en conclusion) meerdere kere in Hebreërs voorkom, waaronder in Hebreërs 3:1-4:14 en in Hebreërs 8:1-10:10. Verder toon hy (1990:217) aan dat die Hebreërskrywer self in 13:22 die aard van die geskrif as logos parakleseoos tipeer, en dat hierdie woord ook met verwysing na homilieë in Handelinge 13:15 en 2 Makkabeërs 15:11 gebruik word. Hierdie drie tekste is so belangrik dat dit volledig hier aangehaal word:

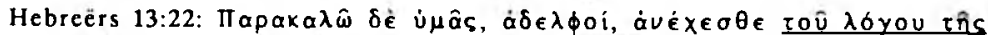

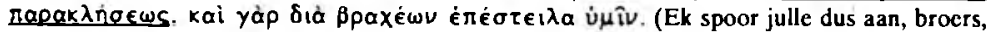
julle moet ag slaan op hierdie woord van paraklese, al het ek ook kortliks aan julle geskrywe.)

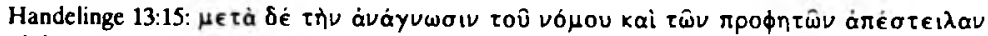

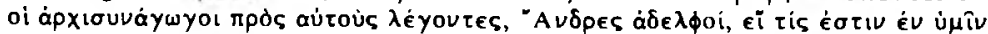

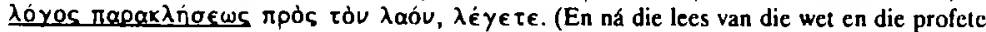
het die leiers van die sinagoge na hulle gestuur en gesê: "Broers, as julle 'n woord van paraklese - bemocdiging/opwekking/troos - vir die volk het, sê dit".) 


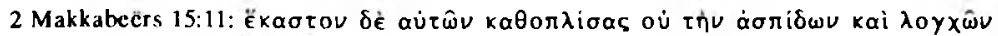

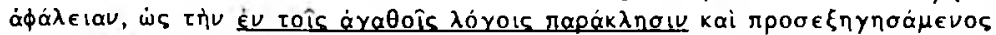

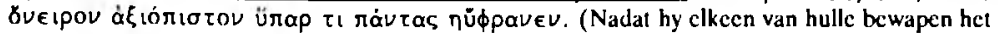
nic sosecr met skilde $\mathrm{en}$ spiese nic, as met dic paraklese deur goeie woorde en nadat hy (aan hullc) ' $n$ droom vertel het wat werd is om tc glo as icts wat almal wakkergemaak/opgewek het.)

Die term word dus nie gekies bloot omdat dit een maal in Hebreërs voorkom nie - dit word gebruik om 'n vorm te benoem wat in terme van formele en strukturele oorwegings geïdentifiseer is. In sowel die Handelinge- as in die 2 Makkabeërkontekste

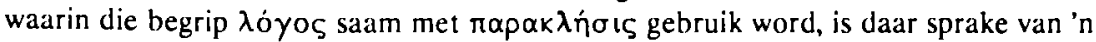
toespraak of rede wat deur iemand gelewer word. Verder is dit ook belangrik om daarop te let dat hierdie tipering van Hebreërs as paraklesis nie bloot op grond van die enkelvoudige voorkoms van die woord $\pi \alpha \rho \alpha k \lambda \dot{n} \sigma \iota \varsigma$ geskied nie, maar dat daar in al drie die kontekste waarna verwys word (Hebreërs, Handelinge en 2 Makkabeërs) die

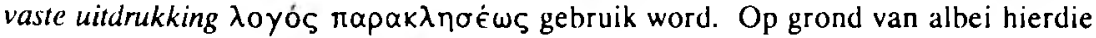
redes is die tipering van Hebreërs as paraklese meer verantwoord as byvoorbeeld om die tweede helfte van Efesiërs as paraklese te tipeer.

Attridge (1990:217) se definisie lui soos volg:

\begin{abstract}
Paraclesis, I suggest, is the ncwly minted rhclorical form that actualizes traditional scripture for a community in a non-traditional environment. It certainly has affinitics with the classical forms of oratory, and those who regularly practised it probably had some training in rhetorical art, but paraclesis is in fact a mutant on the evolutionary trail of ancient rhetoric.
\end{abstract}

Hierdie definisie is na ons oortuiging oortuigend en deeglik begrond en kan as belangrikste rede aangevoer word waarom die term paraklese nie as generiese term vir alle moral exhortation in die Nuwe Testament geskik is nie.

\title{
4. GEVOLGTRIKKING
}

Moral exhortation kom in baie vorme, style, en kontekste in die Nuwe Testament voor. Inhoudelik en vormlik is die moral exhortation nie monolities nie (soos Malherbe aangetoon het): die nie-Christelike skrywers se moral exhonation is nie monolities nie, so ook nie die Christelike skrywers s'n nie. Om dus enigsins so iets soos 'n generiese term vir so 'n komplekse saak te gebruik, is op sigself al 'n probleem. Dit is so onmoontlik as om 'n generiese term te gebruik vir sowel maanlandings as diepseeduiktogte. Miskien maak hierdie analoog die saak wat in hierdie artikel beredeneer word die beste duidelik: dit is duidelik dat daar iets gemeenskapliks aan maanlandings en diepseeduiktogte is. Maar die oomblik wat één generiese term daarvoor gebruik word, word dit moeilik om terselfdertyd ook steeds genoegsaam uitdrukking te gee aan die groot verskille daartussen. 
Alhoewel Malherbe, Stowers, Gammie en Attridge almal 'n breë vergelykingsbasis gebruik (anders as die paraklese-artikels wat net met die Nuwe Testament werk) en alhoewel Malherbe-hulle vir hulle terminologie en hulle onderskeidings gebruik maak van antieke teoretiese geskrifte, los dit nog nie die probleem op nie. Die volgende opmerking van Stowers is hier belangrik:

The terminology, types of literature, and translations associated with exhortation and advice can be very confusing and require explanation. There is much overlapping and ambiguous terminology, which is partly duc to the fact that exhortation was never systematically treated by rhetoricians (1986:91).

Aune (1987:161-162) kritiseer dan ook Stowers se tipologie op geldige punte. Daar is reeds gewys op Attridge se geldige kritiek teen Gammie se taksonomie. Ook Malherbe en Stowers verskil onderling - Stowers onderskei byvoorbeeld baie meer kategorieë as Malherbe (wat slegs protrepsis, paraenesis en diatribe onderskei). Daar is dus ook in die moderne navorsing oor moral exhortation onderling baie uiteenlopende menings, waarskynlik deels toe te skryf, soos Stowers (1986:91) sê, aan die feit dat ook die antieke mense hierdie dinge nooit sistematies uiteengesit het nie. In die lig hiervan kom ons tot die volgende gevolgtrekking:

- Paraklese is nie geskik as generiese term vir alle Nuwe-Testamentiese moral exhortation nie. Dit is egter wel 'n goeie benaming vir een sub-genre onder die saamgestelde sub-genre Paraenesis, wat op sy beurt weer 'n subkategorie onder die sekondère genre paraenetiese literatuur is. (Kyk by 3.3 vir' $n$ verduideliking van hierdie terme.)

- Paraenesis is ook nie geskik as generiese term nie, want dit verhef ook een sub-kategorie tot oorkoepelende kategorie. Die verskeidenheid en nuanseverskille van Nuwe-Testamentiese moral exhortation word dus ook met paraenesis nie suksesvol benoem nie.

Dit bly dus 'n vraag of daar wel 'n geskikte generiese term gevind kan word - én of dit enigsins wenslik is om sodanige term te probeer vind en te probeer yk. Dat die skrywers van die Nuwe Testament - soos vele van hulle tydgenote - op velerlei wyses hulle lesers getroos het, vermaan en berispe het, opgeroep het tot die aanvaarding van 'n nuwe lewenstyl en waardesisteem, aangemoedig het tot volharding in 'n lewenstyl wat hulle reeds aangeneem het, en so meer, is duidelik en hoef kwalik beredeneer te word. Moontlik sal daar meer reg geskied aan hierdie materiaal indien die verskeidenheid daarvan nie uit die oog verloor word nie, iets wat maklik kan gebeur wanneer dit alles onder een term saamgevat word. 


\section{BIBLIOGRAFIE}

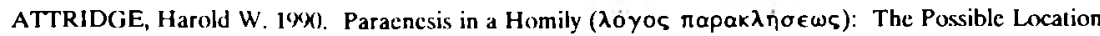
of, and Socialization in, the 'Epistle to the Hebrews'. Semeia, 50:211-226.

AUNE, D.E. 1987. The New Testament and Its Litcrary Environment. Philadelphia : The Westminster Press.

BARR, J. 1961. The Semantics of Biblical Language. Oxford : Oxford University Press.

CARSON, D.A. 1984. Exegetical Fallacies. Grand Rapids, Mich. : Baker Book House.

EXLER, F.X.J. 1923. The Form of the Ancient Greck Lelter : A Study in Greek Epistolography. Washington, D.C.: Catholic University of America. (Ph.D. Dissertation.)

FLOOR, L. 1974. Dic indikatief en imperatief in dic prediking. In die Skrifig, 29(7):7-20, Maart.

FLOOR, L. 1990 . Dic verhouding tussen indikatief en paraklese in dic Nuwc Testament, tocgelig vanuit die eerste bricf aan die Tessalonisense. In die Sknjlig, 24(2):155-165, Junic.

GAMMIE, J.G. 1990. Paraenetic Literature: Toward the Morphology of a Secondary Genre. Semeia, 50:41-80.

JORDAAN, G.J.C. 190. Dic verhouding lussen indikatief en paraklese in die brief aan dic Efesiërs. In die Skriflig, 24(1):49-70 Maart.

KIM, C.H. 1972. The Familiar Letter of Recommendation. Missoula, Mont. : Scholars Press.

KOESTER, H. 1982. Introduction to the New Testament. Vol. 1. History, Culture and Religion of the Hellenistic Age. Philadelphia : Fortress Press. (Hermencia: Foundations and Facets.)

KRUGER, M.A. 1990. Indikaticf cn paraklese in Romcine. In die Skriflig, 24(1):27-48, Maart.

LABUSCAGNE, G.C.P. 1981. Dic indikatief $\mathrm{en}$ dic imperatief in die prediking. Potchefstroom : PU vir CHO (Th.M.-verhandeling.)

LEECH, G. 1983. Principles of Pragmatics. London : Longman.

LOUW. J.P. 1982. Semantics of New Testament Greek. Philadelphia, Pa. : Fortress.

LOUW, J.P. \& NIDA, E.A 1988. Greck-English Lexicon of the New Testament Based on Semantic Domains. New York : UBS

MALHERBE, A.J. 198\%. Moral Exhortation, a Greco-Roman Source Book. Philadelphia : Westminster. (Library of Early Christianity Vol. 4.)

MALHERBE, A.J. 1988. Ancient Epistolary Theorists. SBL Sources for Biblical Siudy 19. Atlanta, Ga. : Scholars Press.

MOULTON, J.H. \& MILLIGAN, G. 1974. The Vocabulary of the Girck Testament. illustrated from the Papyri and other Lilerary Sources. Grand Rapids : Ecrdmans.

MULLINS, T.Y. 1962. Pelition as Litcrary Form. Norum Testamenrum, 5:46-54.

PERDUE, L.G. 1\%(T). The Social Characicr of Paracnesis and Paracnetic Literature. Semeia, 50:1-39.

ROBBINS, V.K. 1990. A Socio-Rhetorical Response: Contexts of Interaction and Forms of Exhortation. Semeia, 50:261-271.

SILVA, M. 1983. Biblical Words and their Mcaning. An Introduction to Lexical Semantics. Grand Rapids, Mich, : Academic.

STOWERS, S.K. 1986. Lelter Writing in Greco-Roman Antiquity. Philadelphia : Westminster. (Library of Early Christianity Vol 5.)

VAN RENSBURG, Fika J. 1990. Indikaticf en paraklese in 1 Petrus en die implikasie daarvan vir die kcrklike prediking vandag. In die Skriflig, 24(1):71-101, Maart.

VENTER, C.J.H.. 1990. Indikaticf en paraklese in die verkondiging met tocligting uit die Pastorale Bricwe. In die Skrifig, 24(1):1-26, Maart.

VENTER, C.J.H. 1985. Dic Pauliniese paranese in Romeine 12-15 - 'n eksegetiese studie. Potchefstroom : PU vir CHO (Th.D.-procfskrif.)

WENDLAND, E.R. 1990. What is Truth? Semantic Density and the Language of the Johannine Epistles (with special reference to 2 John). Neotestamentica, 24(2):301-33.

WHITE, J.L. 1984. New Testament Epistolary Literature in the Framework of Ancient Epistolography. Aufstieg und Nicdergang der Römische Welt Il(25.2):1730-56. 
